\title{
Obstacles In Preparation For Innovation In The Government Case Study: Center For Education And Training Of Indonesian Ministry Of Manpower (Pusdiklat Kemenaker)
}

\author{
Vetty Ilona \\ Department of Administration, \\ Faculty of Administration \\ Universitas Indonesia \\ Depok, Indonesia \\ Email: vetty04@yahoo.com
}

\author{
Lina Miftahul Jannah \\ Department of Administration, \\ Faculty of Administration \\ Universitas Indonesia \\ Depok, Indonesia \\ Email: linamjannah@yahoo.com
}

\begin{abstract}
This research employs post-positivist paradigm and utilizes combined qualitative and quantitative methods. The research data were gathered through in-depth interviews, questionnaires, and document analysis. In 2010, Wang et al. devised five key elements that signal the preparedness of an organization for implementing innovation in its services. The five core elements include investment strategy, risk tolerance, success of innovation, IT experiences, and inter-organizational collaborations. This research demonstrates that the Center for Education and Training of Indonesian Ministry of Manpower, (Pusdiklat Kemnaker), which has made use of eLearning method (as the initial stage of innovation) in its trainings on the basics of manpower, has not been well-prepared in using such a method, notwithstanding the fact that the method is already in use. The implementation of e-Learning method is impeded by a string of challenges, such as unstable internet connection, leader's role, and so forth. Innovation is a requisite for modernizing public administration, but it carries its own risks and does not guarantee a fruitful end. As such, it is of utmost importance to identify and prevent obstacles from hampering innovation. Innovation in public administration faces more complex challenges than that in private sectors. In part, it depends not only on the attitudes or traits of civil servants but also on their environments. According to Giedraiyte, innovation in public sector is generally hindered by such factors as inadequate funding and human resources,
\end{abstract}

regulations, unsupportive management, insufficient incentives for staff, unpredictable response from users, differing risk culture, and resistance. This research concludes that there are two main factors hindering innovation in the Center for Education and Training of Indonesian Ministry of Manpower (Pusdiklat Kemenaker), namely inadequate human resources and budgeting.

Keywords: Obstacles; Innovation; Preparedness; Education and Training; and e-Learning

\section{Introduction}

Education and training programs at the Center for Education and Training of Indonesian Ministry of Manpower (Pusdiklat Kemnaker) are tailored toward accelerating bureaucratic reforms by changing the mindsets of its civil servants. Of all civil servants working under the Ministry, as well as the Agency of Manpower on regional level across Indonesia, only some have had the privilege to attend the trainings conducted by the Ministry (source: Pusdiklat Kemenaker in the workshop 'Fact and Finding' in Gatot Subroto, March 2016). It comes to show that the opportunities to attend trainings and educational programs have not yet been evenly distributed among civil servants, therefore failing to comply with Law No. 5 Year 2014 Article 70 Section 1 and 2, which states that every civil servant reserves the right to competence development. Competence development, as mentioned in Section (1), materializes in educational and training programs, 
seminars, courses, and up-skilling programs.

The number of available functional officials on regional level is small. This, in part, is due to retirement, nonexistent recruitment, and relocation of functional officials within the field of manpower to other fields, which has ensued from the Regional Autonomy law that came into effect. Consequently, the quality of services provided for the public has not been satisfactory. In response to the lack of functional officials in the field of manpower on regional level, the Ministry puts together educational and training programs that are aimed at grooming employees to fill in such positions (source: Pusdiklat Kemenaker in the workshop 'Fact and Finding' in Gatot Subroto, March 2016).

The meeting 'Fact Finding' was attended by Secretary General Ir. Wahab Bangkona, M. Sc. (Gatsu Wednesday, March 16, 2016). Having studied the data presented by the Center for Education and Training of Indonesian Ministry of Manpower (Pusdiklat Kemnaker), he contended that the Minister of Manpower would have to do much to tackle the issues of unequal access to educational and training programs among civil servants. He realized that the Ministry was lagging behind, and its capacity was limited; therefore, he advanced the opinion that new methods and innovation have to be put in place so that the Ministry could catch up with its goal.

e-Learning is one of the innovative methods that Pusdiklat Kemnaker has devised. It was first scheduled to run from April to June 2017. The e-Learning method has so far been used to accommodate the educational and training program (diklat) on 'the Basics of Manpower,' which is a pilot project that forms the basis for future innovation. Pusdiklat Kemnaker is in the business of turning e-Learning method into a platform that integrates classical method, field practice, and e-Learning (source: Pusdiklat Kemenaker in the workshop 'Fact and Finding' in Gatot Subroto, March 2016).

An innovative method that proves to run successfully in several ministries or government agencies may not work out in Pusdiklat Kemnaker. A research published in the journal "The Challenge of Innovation Implementation" validates this premise. It postulates that adopting an innovation that is fruitfully put into practice in one organization does not guarantee the same level of success when it is done in another one. An organization shoulders the burden of creating conditions that a particular innovation necessitates to function successfully (Klein \& Sorra, 1996). Such an innovation cannot be hastily implemented in its entirety within an organization without taking into account the situation and condition of the respective organization. Echoing the same voice, a research in the journal "Organizational Innovation as Competitive Advantage during Global Recession" throws light on the need to employ the internal process approach in an attempt to create innovation within an organization (Sigh, 2011).

Referring to the articles, the author arrives at the conclusion that Pusdiklat Kemnaker should pay attention to its preparedness for innovation before adopting one. It should also identify aspects that might potentially impede the implementation of innovation and work toward minimizing any risks.

Innovation in public sector takes on a distinct form from that in private sector. It is due to the nature of public sector, which has monopoly over the production of goods and services and has no competitors. In addition, the government is rife with bureaucratic culture that is characterized by standardization and formalization of values considered paramount. One example for that is law. According to Schumpeter, as quoted by Bekker, standardization and formalization of values have impacts on risk-taking, and they curb individuals' creativity or initiative (Bekkers \& Steijn, 2011). 
Using the discussion above as a point of departure, this research poses the following question: how is the obstacle in preparation for innovation in the Center for Education and Training of Employees at the Indonesian Ministry of Manpower?

\section{Research Method}

This research adopts post-positivism for its approach. Post-positivist approach requires the researcher to gather data that may support or contradict the theory used. The data collection technique in this research uses convergent parallel mixed method. Convergent parallel mixed method (Creswell, 2009) is that in which a researcher gathers both qualitative and quantitative data, analyzes them separately, and compares the analyses to see whether the results confirm or correspond to each other.

A. Questionnaires with survey

In the survey method, the researcher distributed written questionnaires or performed formal interviews to solicit respondents for information that pertains to the backgrounds, behaviors, and beliefs of a general population (Neuman W. L., 2014). This research employs stratified sampling because the researcher describes that the sample can be taken to represent a particular population on the basis of several characteristics (Charles Teddlie, 2007). The population concerned in this research constitutes all employees of the Center for Education and Training of the Indonesian Ministry of Manpower (Pusdiklat Kemnaker), numbering 76 people. The respondents were selected through stratified sampling.

\section{B. In-depth interviews}

The in-depth interviews were carried out to gather information from the objects of research on the issue being studied. The researcher selected key informants and employees who are in charge of ensuring the preparedness for innovation in Pusdiklat Kemnaker, as well as identifying any foreseeable challenges. The key informants include echelon officials II, III, and IV who play key roles in ensuring Pusdiklat Kemnaker's preparedness for innovation.

C. Document Analysis

This technique was put in place to collect, analyze, and present relevant documents as supporting data in describing Pusdiklat Kemnaker's the preparedness for innovation.

\section{Result}

A. Preparedness for Innovation

In this research, 'Preparedness for Innovation' translates to how an organization prepares itself for a transformation that will turn it into something of greater added value. Five key elements lay the foundation for innovation in services, and therefore they have to be fulfilled. The five key elements are intertwined and are to be holistically prepared (Wang, Hsu, Chiu, \& Wei, 2010).

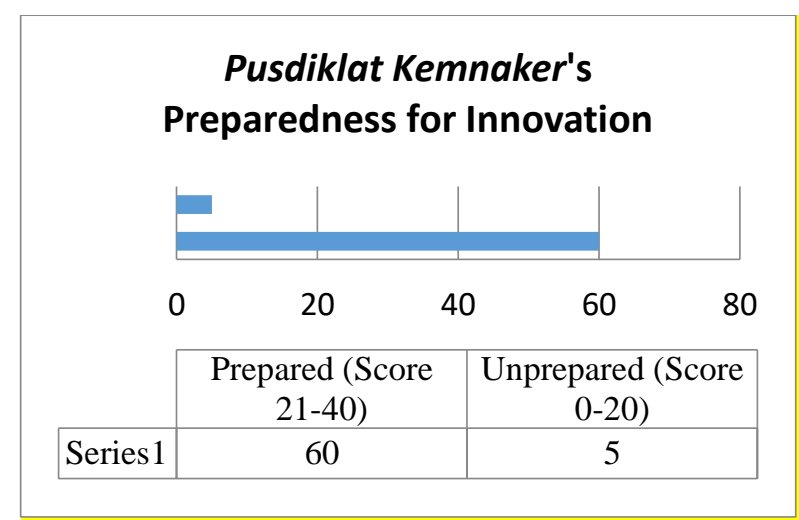

Graphic 3.1. Compiled Results of Questionnaires on Pusdiklat Kemnaker's Preparedness for Innovation $n=65$ people (Source: Primary Data of Research May 2017)

The questionnaire results have been put into a diagram, which demonstrates Pusdiklat Kemnaker's level of preparedness for innovation. The diagram suggests that 60 respondents fall within the category of prepared, whereas 5 people fall within the category of unprepared.

It is, therefore, safe to conclude that Pusdiklat is prepared for an innovation. However, the many reasons that have been put forward by the respondents convey that 
the degree of preparedness has not reached an optimum level. This is supported by the data gathered through interviews, which suggest that, despite the willingness to embrace a change, Pusdiklat and its staff have not yet brought about added value to the organization; therefore, the said change falls beyond the boundary of what is said to be innovation. In addition, a sizeable proportion of the respondents have expressed positive views, but these views do not reflect Pusdiklat's preparedness for innovation.

B. Obstacles in Preparation for Innovation

Obstacles are an inevitable part of an innovation. A public organization has to train its skills to identify and develop management tools to determine the quality and efficiency of innovation process. Pusdiklat Kemnaker's DJJ program has come to naught, and this failure should become a source of lessons for any future innovative programs.

A myriad of obstacles that invariably hamper innovation in public sector include limited funding and human resources, rules and regulations, lack of management support, inadequate incentives for staff, uncertain response from users, risk culture, and resistance. The following diagram presents the results of questionnaires on the obstacles faced by Pusdiklat Kemnaker:

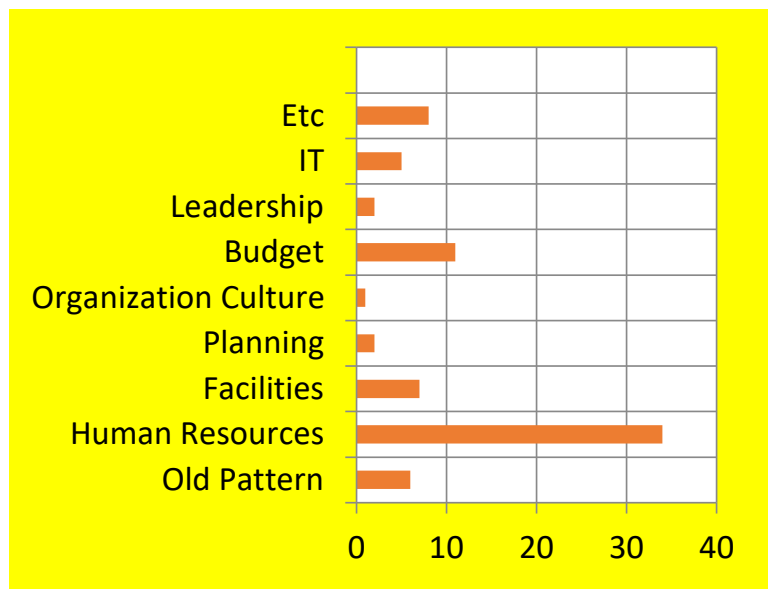

Graphic 3.2. Questionnaire Results on the Obstacles in Innovation faced by Pusdiklat Kemnaker $\mathrm{n}=65$ people
(Source: Primary Data of Research May 2017)

\section{Discussion}

A. Preparedness for Innovation

Peter Drucker postulates that innovation is a condition whereby we exploit what we have had in our organization, be it in the realms of market, knowledge, society, populace, and so forth. Creating innovation carries greater risks than declining it by use of available opportunities. Innovation constitutes hard work (Drucker, 1999).

Another definition is put forth by Trushman and Nadler, saying that innovation comprises two parts: the generation of an idea or invention and the fruitful commercialization of that invention or idea (innovation $=$ invention + exploitation) (Ahmed \& Shepherd, 2010). The red line underlining the two definitions is that innovation is the transformation of idea into something of greater importance that adds up to the added value of a given organization.

Echoing a similar concept, OECD opines that innovation is the implementation of a new or significantly improved product, be it good or service, or process, a new marketing method in business practices, workplace organization or external relations (OECD, 2005). Such a definition paints a picture that innovation can be defined both narrowly and broadly, such as the improvement of a product and the generation of something of greater added value, respectively.

Innovation in public sector is defined as the quest for idea and concept, technology, techniques and methods, and form, system, and procedures that offer some novelty to the creation of mutually beneficial interaction between the government and its people in the hope to tackle societal problems (Bekkers \& Steijn, 2011).

Preparing for innovation is oftentimes considered tantamount to preparing for a change. Preparedness for a 
change means "the cognitive pre-cursor to the behaviors of either resistance to or support for change efforts". In this sense, the idea of 'preparedness' bears some similarity to Lewis' concept of 'unfreezing'; that is, a manifestation of beliefs, behaviors, and the will of members of a given organization about the extent to which a change is needed and how much an organization is in power of making a fruitful change (quoted by Archilles A Armenakis; Stenley G Harris; Kevin W Mossholder, 1993). As Farley (1986) puts it, the state of being prepared for a change can be taken to suggest the varied personalities of a population and is evidently associated with decision-making (quoted by Archilles A Armenakis; Stenley G Harris; Kevin W Mossholder, 1993).

The state of being prepared for innovation is that in which companies and regions can sustain their ability to innovate and how communication can contribute to this. Meanwhile, kesiapan informasi, or the state of being prepared to receive information is defined as the tendency of people to adopt and exploit innovation at the time when the innovation is introduced to them. The level of acceptance of innovation varies according to the breadth of knowledge, acquaintance, and experiences related to technology that inform a person whether to accept or decline innovation (Sulaiman, 2016).

Wang (2010) argues that service innovation comprises comprehensive management activities that are directed toward developing and marketing new services in order to meet prospective customers' needs. Armenakis et al. (1993) introduces the concept "Organization Preparedness" to point out the extent to which an organization is capable of embracing particular changes. The organization places significant emphasis on the need to consider all employees impacted by changes and define the preparedness of the said organization. The latter is so important as to see "the determination of the members of organization, their attitudes, and the will to find out how much a change is needed and the organization's capacity to put it into effect." Innovation preparedness in this research is defined as the condition whereby an organization prepares itself to transform into something that possesses greater added value.

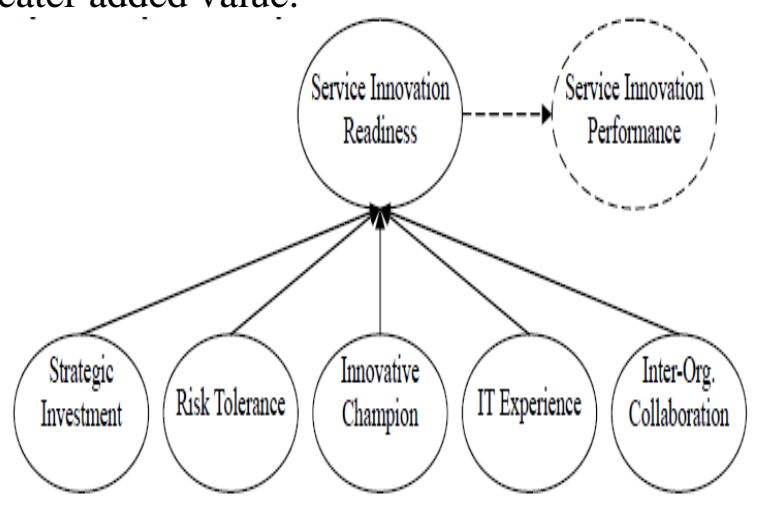

Picture 4.1. Conceptual Framework on Service Innovation (Hwang, Hsu, Yen, Chiu, \& Wei, 2010)

Wang (2010) identifies five key elements that signal an organization's preparedness for service innovation. The document analysis section provides more detailed information on the five key elements. The results of questionnaires and in-depth interviews at Pusdiklat are the followings:

1. Strategic Investment

A strategy is a general action plan that is pieced together to attain a particular goal. A strategy needs to be put in place to ensure that an organization possesses adequate and appropriate resources for the innovation investment to run successfully. Investing resources in innovation does not merely mean that an organization is committed to performing innovation; it also projects an image of organizational leaders' support to the innovation. Wang defines 'strategy investment' as the degree to which an organization is willing to invest and committed to adopting service innovation.

Investing resources in innovation does not merely mean that an organization is committed to performing innovation; it also projects an image of organizational leaders' support to the innovation. The innovation 
concerned in this research comprises that which is created by Pusdiklat Kemnaker in order to reach a goal. To attain the goal, Pusdiklat Kemnaker embarks on its early stage of innovation by creating e-Learning program. A working team has been established to run this program. The team bears the responsibility to undertake, supervise, and to be responsible for the implementation of e-Learning. In addition, the team is also to obliged to make reports on the development of the said innovation to the leaders. One obstacle that impedes the implementation of the innovation is that there has been a change of leader, resulting in the Surat Keputusan (decree) not being able to be legalized on schedule. Nonetheless, the e-Learning program continues to run.

Educational and training programs should be in line with the Ministry of Manpower's strategic plans. Pusdiklat (Center for Education and Training) has a roadmap that outlines its long and shortterm plans. The change of leader should not have become an obstacle in the implementation of innovation. Roadmap should become a guiding light for the leaders to carry out the short and long-term plans, in line with the Ministry of Manpower's strategic plans.

The new service is focused on Pusdiklat Kemnaker's task to educate and train civil servants so that they can acquire particular competence to carry out their duties. In practice, e-Learning assists the employees of Pusdiklat in performing their tasks. However, due to the lack of familiarity with technology, they have troubles accessing this innovation. Also, this innovation is considered as something of closed system. This change has to be done in a holistic manner; otherwise it triggers resistance. Improvement in the areas of employees' competence and innovation infrastructure has to be reached to ease the employees' burden.

Pusdiklat has created procedures for the implementation of this initial stage of innovation (e-Learning). However, according to the questionnaire results, some employees express that the procedures have not yet been optimally put into practice. As such, an improvement in terms of optimality and flexibility needs to be attained for the innovation to run well.

Some employees hold that targets have been well-defined, and some of which have been obtained. However, a few other employees claim to know nothing of the targets and their implementation. That said, the leaders, as well as employees, shoulder the responsibility to maintain good communication so that employees will be aware of their duties, functions, and responsibilities.

2. Risk tolerance

Risk is widely understood as an outcome, possibilities, and subjective value (an action done to reach a goal) (March and Shapira (1987) as quoted by Kwaka \& LaPlace, 2005). Scientists find that, historically speaking, an organization's decision-makers tend to maintain investments or old routines even when investments are not financially advantageous (Barton et al. 1989 as quoted by Wang, Hsu, Yen, Chiu \& Wei, 2010). Risk tolerance in one's attitude toward risk also plays a role in determining a person's tolerance for bearing risk (Bodie and Merton (1999) as quoted by Kwaka \& LaPlace, 2005). Risk tolerance in an organization can be seen through the degree to which an organization is prepared for any loss (costs, human resources and other resources) that might incur when adopting service innovation.

There has not been any supplementary service to tolerate any risk that potentially incurs in Pusdiklat. As of now, Pusdiklat only works on eliminating obstacles that might lead to failure of its program. Budgeting is an issue in the attempt to tolerate risk. Pusdiklat is determined to continue on with its innovation despite the possibility of failure. Potential failure can actually be avoided by preparing resources needed to tolerate risk of failure. However, resources cannot be provided at a short span 
of time. The provision of resources has to be well-planned a year preceding its use.

Pusdiklat has limited speed in embracing change and accommodating the needs of its customers as it is a public organization; therefore, it is bound to existing regulations and laws. However, its leaders are capable of taking appropriate measures in serving the customers well and quickly. Such measures are to be reported and carried out under the consent of the leaders.

Based on the interviews and questionnaires, Pusdiklat believes that chances for e-Learning to fail are very slim. It claims that obstacles and doubts have become challenges facing the implementation of e-Learning program, but they have been well-identified early on and dealt with to ensure that the e-Learning program will not be hampered. Risk tolerance has not been put at the center of attention at this initial stage of innovation.

3. Success of innovation

Leadership is the process of identifying a particular goal and influencing the followers or members to voluntarily attempt to work ((Yukl, 1998) as quoted by (Wang, Hsu, Yen, Chiu, \& Wei, 2010)). Scientists suggest that, after an organization defines its new goals, its elite leaders should commence working to create a change. They have to communicate the goals to members of the organization and encourage them to work toward achieving such goals. For that reason, as the organization decides to make service innovation, its elite leaders should start guiding and directing the members or employees toward investing in the service innovation; such is called 'Innovative Champion,' the extent to which elite leaders guide and encourage employees to contribute their ideas to the service innovation.

In responding to the needs of its customers, Pusdiklat Kemnaker has embarked on an early stage of innovation (e-Learning). The majority of its employees claim that Pusdiklat has introduced this program to its customers, although its implementation might not have hit a satisfying level.

New ideas partly determine the success of an innovation. Based on both interviews and questionnaires, the majority of employees claim to have contributed their ideas to the improvement of Pusdiklat. Some other employees express that their ideas can be contributed only to certain sections of improvement. Entrepreneurship can be stimulated through openness, which would also trigger a train of new ideas that will ultimately help improve the existing innovative program.

The leaders of Pusdiklat are open to and gather new ideas, and such premise is agreed upon by most of the employees. Pusdiklat accepts new ideas and attempt to put them into reality wherever possible. Budgeting has become a major obstacle in making such ideas happen.

Every leader in Pusdiklat strives to exhibit exemplary actions to the employees. However, a frequent change of leaders becomes a source of concern among the employees. The most pivotal task of a new leader of Pusdiklat is to gain the employees' trust to continue the innovation together.

4. IT experience

Information and technology (IT) is an integral part of organizational activities today as it helps increase the performance of organization significantly. Research shows that service innovation that uses IT to introduce new services can improve information dissemination and interorganizational co-ordination ((Menor \& Roth, 2007) as quoted by (Wang, Hsu, Yen, Chiu, \& Wei, 2010)). IT Experience is the condition whereby an organization utilizes IT to facilitate or improve coordination with customers or colleagues, and intensify information dissemination in the attempt to introduce services to customers.

Pusdiklat is starting to use IT to introduce its new services to customers. Information pertaining to its new services are put on its website and flyers. The 
employees' lack of communication with other sections of the organizational body should also be considered with great weight so that customer service quality can be duly ameliorated.

The e-Learning program makes use of IT in all of its services and activities, either through website, Whatsapp, e-mail, or other IT platforms. Thus, efforts need to be done to ensure that the infrastructure used to facilitate these services and activities is constantly improved.

IT evidently gives immense benefits, and the existing IT infrastructure in Pusdiklat can be used to perform a plethora of tasks that include identifying needs of customers, composing reports, assembling evaluations, and so forth. The majority of employees assert that IT infrastructure has so far been able to operate for the purpose of diklat (education and training) only. It has not been optimally used to accommodate other activities related to diklat.

5. Inter-organizational collaboration

Inter-organizational collaboration allows an organization to both widen the breadth and renew its sources, resulting in improved competitiveness ((Hunt and Morgan, 1996) as quoted by (Wang, Hsu, Yen, Chiu, \& Wei, 2010)). Interorganizational collaboration translates to the condition in which an organization is able to disseminate information and respond to the changing markets together with its partners, either from within or outside the organization. (Wang, Hsu, Yen, Chiu, \& Wei, 2010).

Pusdiklat Kemnaker is not an independent organization devoid of any relationships with other organizations or units. Rather, it invariably collaborates with other units in the Indonesian Ministry of Manpower, as well as other public or private institutions. Its closest partners involve Biro Organisasi dan Kepegawaian (Bureau of Organization and Employee Affairs) and other internal units.

Exchange of information becomes a focal point in this collaboration as decision- making process is largely based on the information received through this network. Pusdiklat shares information with its partners through meetings, reports, and so on. The existing collaboration has not run satisfactorily, and Pusdiklat needs to make improvement in this area.

Pusdiklat has tapped into a collaboration with internal units; however, collaboration with external units (local governments, universities, public and private institutions in or outside Indonesia) remains stagnant. As such, future improvement would have to include bettering collaboration with the said external institutions (especially Universitas Terbuka/Open University).

In any form of collaboration, an organization has to abide by rules, and it is as important to own a platform that allows Pusdiklat to collaborate with other institutions and exchange information based on which decisions are made.

Pusdiklat is aware of the need to respond quickly to changes occurring within or outside its organization. Its existing collaboration network has not run well due to an obstacle, namely budgeting. The head of Pusdiklat should find ways to keep its collaboration running despite the lack of funding and without breaching any existing regulations.

e-Learning is an initial stage of innovation implemented in Pusdiklat. However, Pusdiklat proves to be unprepared for running such a program. It can be seen by the many indicators of preparedness that Pusdiklat has not been able to show, resulting in the e-Learning program's unsatisfactory implementation. It is of great importance to conduct an early evaluation to point out areas that need improvement (Wang, Hsu, Yen, Chiu, \& Wei, 2010). The early evaluation helps to ascertain that the implementation of innovation is on the right track to its goal. Two major obstacles impeding innovation in Pusdiklat Kemnaker are:

1. Human Resources 
New knowledge, techniques, and procedures are required. Technology can transform employees' work styles, and they have to find ways to invent technology. It results in employees growing apathetic. Their careers become unstable, wellsecured, and readily accessible. Employees opt for job areas that they are good at or have convinced their colleagues and managers about their work. However, status quo remains at the heart of their focus.

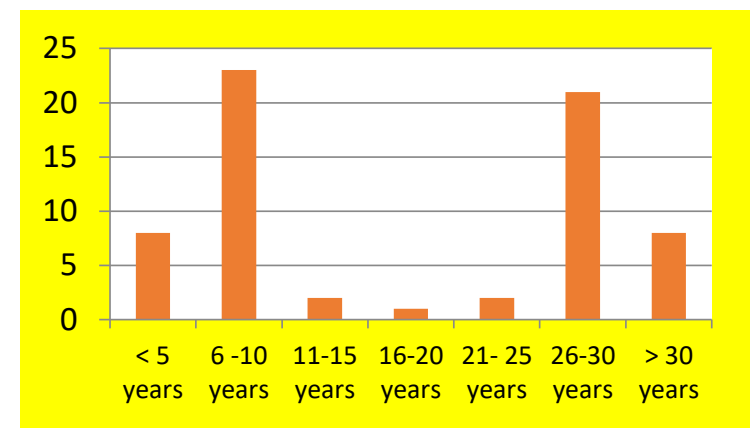

Graphic 4.2 Questionnaire Results on the Length of Working Periods in Pusdiklat $\mathrm{n}=65$ people

(Source: Primary Data of Research May 2017)

The human resources in Pusdiklat comprise a large number of elderly employees with well over 25 years of service. In addition, there has not been a move to rotate their employees' assigned jobs throughout their employment. Such is a challenge in the implementation of innovation in the realm of education and training (diklat), which widely makes use of technology.

According to the Office of Employees' Affairs, some of Pusdiklat's employees have earned high school education or below. The following is a diagram that demonstrates Pusdiklat's human resources based on their education levels. Two things can be done to ameliorate the employees' competence: train existing employees or recruit new employees who possess skills needed by Pusdiklat.

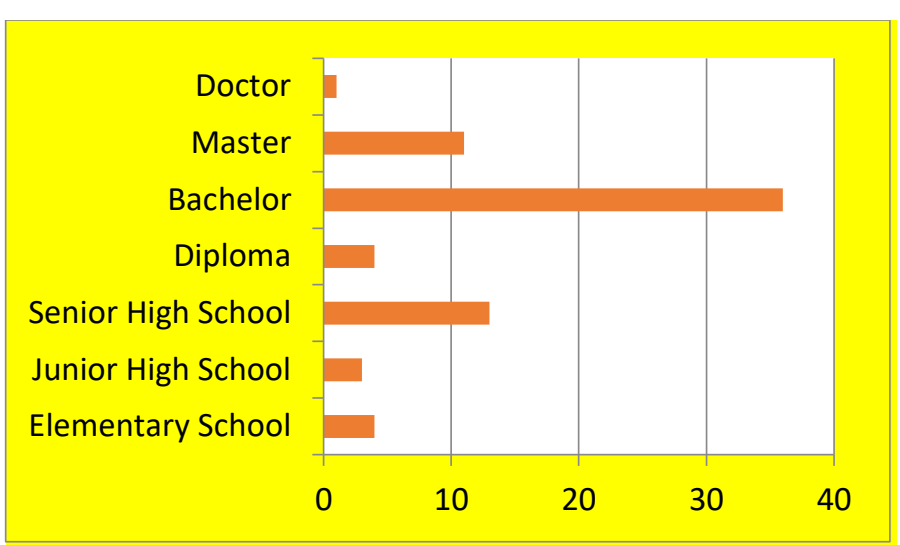

Graphic 4.3 Condition of Pusdiklat's

Employees based on their Education

Levels

(Source: Pusdiklat's Office of Employees' Affairs, February 2017)

To cope with the problem of inadequate competence of its human resources, Pusdiklat can recruit new employees either from within the Ministry or outside it. However, with the moratorium in place, Pusdiklat is temporarily unable to recruit new employees from outside the Ministry. Pusdiklat can increase the competence of its employees by conducting short trainings on the implementation of innovation. Gradual improvement of competence should be monitored and reported on a regular basis so that the implementation of innovation can run smoothly.

\section{Budgeting}

An innovative project requires substantial financial resources. The inflexibility of budgeting in the government has made budgeting a major problem. This is partly due to the principles of centralization and decentralization of power on all levels of government, and partly because of the very tight financial administration of the government as well as unalterable budgeting. To put it simply, a public institution has to be supported by flexible flow of funding or funding that can be kept for efficiency. Because of such an unstable source of funding, Borrins puts forth the idea that budgeting reforms have to be conducted in public sector in order to increase innovation. 


\section{Conclusion and Suggestions}

A. Conclusion

1. The Center for Education and Training of Indonesian Ministry of Manpower (Pusdiklat Kemnaker) has not been prepared for the implementation of Pusdiklat Kemnaker's innovation for years 2016-2020. Pusdiklat Kemnaker has so far conducted only the initial stage of innovation, switching the classical method of diklat (education and training) to eLearning method. This method, however, cannot be deemed as an innovation as it has not contributed added-value to Pusdiklat. Several challenges that hinder the implementation of innovation include inadequate human resources, budgeting, change of leaders, internet connection, organizational culture, and infrastructure. Meanwhile, the two biggest challenges facing the implementation of said innovation involve inadequate human resources and tight budgeting.

\section{B. Suggestions}

a. Pusdiklat is lagging behind its schedule in its implementation of innovation. This is due to frequent change of leaders. As such, Pusdiklat needs to ponder the change of leader as it has caused its work plans to run over the schedule. In addition, Pusdiklat should also design long and short-term plans for its 'roadmap' so that the change of leaders will not have too much impact on the work plans that have been outlined by a previous leader.

b. It is of utmost importance to ameliorate Pusdiklat's human resources through education and training programs, which will serve as a long-term investment although no immediate impacts would be evident. Kemnaker should pay attention to the budgeting and allocate funding for the improvement of Pusdiklat's human resources.

c. Kemnaker does not have a neat and structured archival system yet. Archives can serve as a source of information on which learning and decision-making are based. It is, therefore, recommended that
Kemnaker builds an organized archival system and employs archivists.

d. Pusdiklat has not been adequately supported by an advanced IT system for its e-Learning method. It is recommended that Pusdiklat builds a stronger IT system coupled with human resources so that it will be prepared for any possible risk that might incur along the way.

e. Leaders of Pusdiklat should be open to new ideas and information from all parties in order to improve the implementation of innovation.

f. Pusdiklat should do much to ameliorate its human resources by doing study exchanges to either private or public centers for education and training that have been successful in running their education and training programs.

g. Pusdiklat should improve the quality of its education and training programs, as well as its collaboration with relevant external or internal parties in hope to attract more people to its education and training programs.

h. Research on the obstacles hindering the implementation of innovation in the government should be continued by future researchers so that the said innovation can be improved.

\section{REFERENCES}

Achilles A Armenakis; Stenley G Harris; Kevin W Mossholder. (1993). Creating Readiness for Organizational Changes. Human Relations Vol 46 No.6, 681-703.

Armenakis, A. A., \& Bedeian, A. G. (1999). Organizational Change: A Review of Theory and Research in the 1990s. Journal of Management, Vol. 25, No. 3, 293-315.

Bekkers, V., \& Steijn, J. E. (2011). Innovation in Public Sector Linking Capacity and Leadership. New York: Palgrave Macmilan.

Malcolm Knowles, E. F. (2005). The adulth learner 6th edition. California: Elsevier. 
Michael Armstrong. (2009). Armstrong's Handbook of Human Resource Management Practice 11th edition. London and Philadelphia: Kogen page

Paton, R. A., \& Calman, M. (2008). Change Manahement; A Guide to Effective Implementation 3rd Edition. Sage.

Sigh, S. K. (2011). Organizational Innovation as Competitive Advantage During Flobal Recession. Indian Journal of Industrial Relations, Vol. 46, No. 4, Beyond GDP, 713-725.

Stone, R. J. (2011). Human Resource Management 7th edition. Australia: John Wiley \& Sons.

Sulaiman, A. H. (2016). The Effect of User's Informational-Based Readiness on innovation acceptance. International Journal of Bank Marketing, Vol. 27 Iss 1, pp. $76-100$.

Wang, W., Hsu, H. S., Yen, H. R., Chiu, H.C., \& Wei, C.-P. (2010). Developing and Validating Service Innovation Readiness. Association for Information System (AIS Electronic Library). 